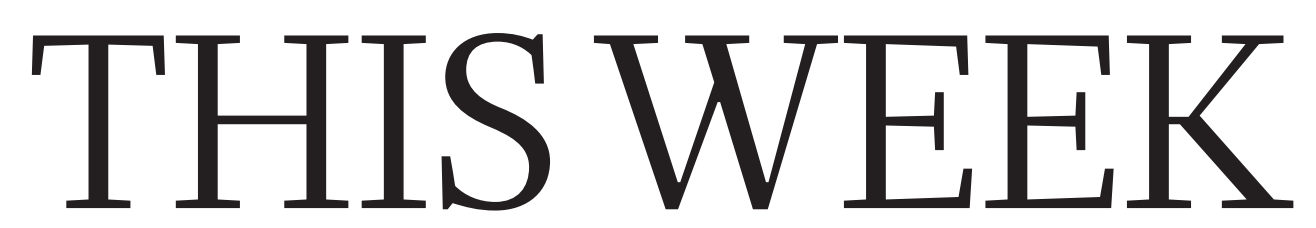

EDITORIALS

LOCAL HEROES How to solve the biodiversity crisis, one habitat at a time $\mathbf{p . 7 5 2}$
PROGRAMMING Why all computer code is actually as bad as yours $\mathbf{p . 7 5 3}$
FEATHER RIGHT Coloured parrot wings beat the bacteria $\mathbf{p . 7 5 4}$

\title{
Politics without the poison
}

\author{
If the US midterm elections are to kickstart progress in Congress on urgent issues such \\ as climate and basic research, the mudslinging and mayhem have got to stop.
}

\begin{abstract}
$\mathrm{A}$ $s$ the race to next month's midterm elections for the US Congress enters the home straight, scientists and non-scientists alike could be forgiven a shudder of disgust over their elected representatives. Hyper-partisan fighting in recent years, characterized by venom, invective and mindless, just-say-no obstructionism, has made progress virtually impossible on national priorities such as climate, immigration reform and crumbling infrastructure. Despite survey after survey showing that voters want to see hands across the political divide, US politicians have been unable or unwilling to make productive deals to address the nation's clear and present problems.

Asked to describe how the United States fell short of ideal at a focus group last week, one voter from Keansburg, New Jersey, described a food fight in the cafeteria of a local middle school. The students had gleefully flung chicken casserole at each other, then left it to the school staff to clean up the mess. According to a New York Times reporter sitting in on the focus group, other participants struck much the same note. Candidates who emerge victorious should keep that Keansburg story in mind. Voters on all sides sense that too many privileged Americans, including the politicians for whom they end up casting their ballots, are engaged in reckless behaviour that leaves a mess behind.
\end{abstract}

\section{CHANCE FOR EARLY ACTION}

The situation is not entirely irredeemable, even if, as seems likely, the Republicans take control of one or both houses of Congress and set themselves up in opposition to the administration. The new Congress has a number of ready-made opportunities for early action.

Health-care reform, for example, has been a food fight all of its own (see page 763). The complex measure was finally passed last March with no Republican support, in the face of baseless propaganda about provisions such as 'death panels', which would supposedly decide whose life was valuable enough to save. One thing that both sides should be able to agree is the need to slow the explosive growth in the cost of health care. A key way to achieve those savings is the widespread use of electronic medical records, which promise to make a national health-care system more efficient overall, and, with appropriate privacy safeguards, could provide researchers with a rich new source of public-health statistics. Another way is through funds for comparative-effectiveness research, which compiles empirical data about which treatments work best for each condition. Comparative effectiveness has been controversial, and the source of some of the death-panel rhetoric. But both approaches are essential tools in cost control. Whatever happens to the reform bill overall, the new Congress should continue to fund them vigorously.

Just as contentious are climate and energy (see page 762). The current Congress has failed to pass cap-and-trade legislation designed to limit US greenhouse-gas emissions, thanks chiefly to strong Republican opposition. Even on this poisoned political ground, everyone in the new Congress should be able to agree to a strong push on energy efficiency.
Such an effort could come through federal efficiency codes for power plants and transmission lines, or for new and retrofitted buildings. Increased efficiency, by whatever route, is the easiest and cheapest way to limit carbon emissions, and has the added appeal of decreasing the nation's dependence on imported oil. Politicians unwilling to make the first argument may well be persuaded by the second.

If Congress cannot even agree to that, when legislators are totally gridlocked on a major policy issue, often the easiest way forward is to put more money into research and development, which has long enjoyed bipartisan support on Capitol Hill. The Advanced Research

"Voters sense
that too many
privileged
Americans,
politicians
included, are
behaving
recklessly."
Projects Agency-Energy, created by the 2009 Stimulus Act, offers Congress a ready-made mechanism to funnel money into energy research (see page 760). And the 2007 America COMPETES Act, assuming it is renewed after the elections, gives Congress a mechanism to boost physical-sciences funding. Granted, the new Congress may not be especially generous to science, given anxiety over the federal deficit. But legislators would be foolish to subject research to the deep cuts proposed in the United Kingdom and elsewhere. Quite aside from the disruption that would cause for individual science programmes, it would undermine the potential for long-term economic growth.

\section{RESEARCH OFF THE RAILS}

Finally, the new Congress should squarely address the question of federally funded research on human embryonic stem (ES) cells. Such studies are currently at the mercy of the courts: guidelines set out by President Barack Obama in 2009 were challenged as a violation of the 1995 Dickey-Wicker amendment, legislation that bars federal funding for any research in which human embryos are destroyed. How the amendment applies to current research is debatable, to say the least - it was written three years before human ES cells were even isolated - and the case could take years to resolve. But in the meantime, investigators in the field could be wracked by injunctions that force them to stop work any time a judge decrees it, as has already happened once.

Congress should take this issue out of the courts by clarifying exactly what it wants for human ES-cell research. The best route would be to explicitly endorse the continuation of such work under the Obama guidelines. But even if Congress instead bars federal funding for the research completely, at least that would be a decision. Scientists could plan their careers around it. To leave things as they are, with researchers jerked around and left in limbo, would be unconscionable. Congress is there to make decisions. Those decisions should be based on sound evidence and public and national interest. Its members must remember that, unlike the Keansburg school floors, there is no one available to clean up their mess. 